Article

\title{
The Use of Acidic Hydrolysates after Furfural Production from Sugar Waste Biomass as a Fermentation Medium in the Biotechnological Production of Hydrogen
}

\author{
Weronika Cieciura-Włoch ${ }^{1, * D}$, Michał Binczarski ${ }^{2}$, Jolanta Tomaszewska ${ }^{2}$, \\ Sebastian Borowski ${ }^{1}$, Jarosław Domański ${ }^{1}$ (D), Piotr Dziugan ${ }^{1}$ and Izabela Witońska ${ }^{2}$ (D) \\ 1 Institute of Fermentation Technology and Microbiology, Faculty of Biotechnology and Food Science, \\ Lodz University of Technology, Wolczanska 171/173, 90-924 Lodz, Poland \\ 2 Institute of General and Ecological Chemistry, Lodz University of Technology, Wolczanska 171/173, \\ 90-924 Lodz, Poland \\ * Correspondence: weronika.cieciura-wloch@edu.p.lodz.pl
}

Received: 31 July 2019; Accepted: 19 August 2019; Published: 21 August 2019

\begin{abstract}
This study investigates a simultaneous processing of sugar beet pulp (SBP) for furfural, hydrogen and methane production using various pretreatment methods. In the experiments, sugar beet pulp was first subjected to thermal and thermochemical pretreatment at $140^{\circ} \mathrm{C}$. Then hydrolysates from these operations were investigated for their potential for methane and hydrogen production in batch tests. The experiments showed that thermal pretreatment of SBP resulted in the highest biogas and methane yields of $945 \mathrm{dm}^{3} / \mathrm{kg}$ volatile solids (VS) and $374 \mathrm{dm}^{3} \mathrm{CH}_{4} / \mathrm{kg} \mathrm{VS}$, respectively, and a moderate hydrogen production of $113 \mathrm{dm}^{3} \mathrm{H}_{2} / \mathrm{kg}$ VS, which corresponded to a calculated energy production of $142 \mathrm{kWh} / \mathrm{t}$; however, only low amount of furfural was obtained $(1.63 \mathrm{~g} / \mathrm{L})$. Conversely, the highest furfural yield of $12 \mathrm{~g} / \mathrm{L}$ was achieved via thermochemical pretreatment of SBP; however, biogas production from hydrolysate was much lower $\left(215 \mathrm{dm}^{3} / \mathrm{kg}\right.$ VS) and contained only $67 \mathrm{dm}^{3} / \mathrm{kg}$ VS of hydrogen. Meanwhile, in the experiment with lower amounts of sulfuric acid $(2 \%)$ used for pretreatment, a moderate furfural production of $4 \mathrm{~g} / \mathrm{L}$ was achieved with as high as $220 \mathrm{dm}^{3} / \mathrm{kg}$ VS of hydrogen and the corresponding energy yield of $75 \mathrm{kWh} / \mathrm{t}$.
\end{abstract}

Keywords: furfural; hydrogen; sugar beet pulp; dark fermentation

\section{Introduction}

Sugar beet pulp (SBP) is a residue obtained after large scale sugar production. According to the Central Statistical Office and Institute of Agricultural Economics and Food Economy, in the period from September 2018 to January 2019, a total of 2.6 million tons of sugar was produced in Poland, which was greater than production in the 2017-2018 season (2.3 million tons). Südzuker Polska reported that the average sugar production from 1 ton of beet is $150 \mathrm{~kg}$ and resulted in the generation of $250 \mathrm{~kg}$ of wet SBP. Thus, more than 4.3 million tons of SBP were produced in Poland in the 2018-2019 season, which led to sugar producers needing proper management of this waste. Until now, sugar beet pulp is mostly used in a dried form or as silage for cattle feeding. However, changes in the European Union's agricultural policy to allow for increasing sugar production may result in the overproduction of SPB [1,2].

The chemical composition and low cost of SBP makes this substrate attractive for many branches of the chemical industry for its biotechnological [3] and chemical [4] properties. Sugar beet pulp is a type of lignocellulosic biomass and consists mostly of carbohydrates (cellulose 22-30\%, hemicellulose 24-32\%, 
lignin $1-2 \%$ ) and polymeric saccharides (pectin $38-62 \%$ of the dry matter) [3,5]. Enzymatic, chemical, or thermal hydrolysis of these polymeric substances is a crucial step for valorizing SPB. The main monosaccharides obtained by the hydrolysis of SBP are glucose, fructose, mannose, galactose, galacturonic acid, rhamnose, raffinose, xylose, and arabinose [6,7]. These monosaccharides can successfully be used as sources of sugars for microorganisms (e.g., lactic acid bacteria, yeasts, fungi, etc.) [8-11] or as substrates in chemical syntheses, e.g., for the production of fuels (bioethanol, methane, hydrogen), solvents, polymers, etc. [4,12-14].

In addition to simple sugars obtained by the depolymerization of cellulose and hemicelluloses, the SBP hydrolysates may contain other valuable chemicals including furfural, 5-hydroxymethylfurfural (5-HMF) [15,16], vanillin (4-hydroxy-3-methoxybenzaldehyde) [17] and levulinic acid (LA) [18,19]. Furfural is the main product among the aforementioned compounds, whereas 5-HMF and levulinic acid are yielded in much lower amounts. Furfural is formed from pentoses released from hemicellulose by acid-catalyzed dehydration. This process occurs relatively easily at elevated temperatures of $130-160{ }^{\circ} \mathrm{C}[20,21]$ in the presence of mineral acids or solid acid catalysts [22,23]. Furfural, because of its highly functionalized molecular structure, is a sustainable platform molecule that can be valorized to value-added chemicals containing oxygen atoms [24]. Since the main polysaccharides building the structure of SBP are hemicelluloses, it seems to justify the use of acidic treatment for hydrolysis of this material to obtain furfural. On the other hand, the residue after acidic hydrolysis of SBP at elevated temperature and pressure still contains a pool of unprocessed pentoses and hexoses, which can be used for biotechnological production of biofuels like bioethanol or hydrogen-rich biogas. In this context, dark fermentation (DF) is a promising technology that allows for the conversion of monosaccharides into hydrogen, which is regarded as a nearly ideal fuel since it does not cause emissions when burned for energy recovery $[3,21]$. Several substrates have been evaluated for their potential of hydrogen production via dark fermentation. As stated in the literature, the main materials applied for dark fermentation were food waste [25-30] and municipal solid waste [30,31], which gave moderate to high hydrogen yields. The DF experiments were also performed using cheese whey [32,33], agricultural residues [34], biorefinery liquid streams [35], distillery wastewater [36], cassava stillage [37], as well as byproduct from sugar production and processing $[38,39]$. However, very little has been written about the use of hydrolysates after thermal and chemical processing of wastes, including sugar beet pulp [40]. The dark fermentation process is often combined with anaerobic digestion in a two-stage process, which allows for hydrogen and methane production from waste [27,29,41].

Fermentative production of $\mathrm{H}_{2}$ is carried out by a wide range of microorganisms belonging to strictly anaerobic or facultative anaerobic bacteria such as Clostridium spp., Escherichia spp. as well as some species of Bacillus spp., Enterobacter spp., Ruminococcus spp., Klebsiella spp. and others [42]. However, furfural may inhibit the growth of these bacteria, particularly when pure strains are used for hydrogen production $[43,44]$. Not only is the application of pure cultures expensive but it is also problematic due to the high risk of contamination by wild species [44]. Hence, the use of microbial consortia from natural and industrial environments (like anaerobic sludge) is justified because these organisms are better adapted to heterogeneous substrates and non-sterile process conditions. Municipal sewage sludge after anaerobic digestion seems to be a good material served as inoculum for dark fermentation. However, due to the presence of hydrogen-consuming microorganisms, this inoculum needs preliminary treatment. In our previous research, inactivation of non-spore bacteria and methanogens was achieved by $\mathrm{pH}$ adjustment to 5.5 and thermal pretreatment of inoculum performed at $80^{\circ} \mathrm{C}[26,44]$.

This research is the first to propose the complex valorization of sugar beet pulp for combined production of furfural by thermochemical treatment and hydrogen by dark fermentation. Experimentally, the thermal and thermochemical pretreatment of sugar beet pulp prior to dark fermentation for hydrogen generation was performed. The novelty of the described method also relies on the use of lower temperatures (up to $140{ }^{\circ} \mathrm{C}$ ) in the first stage in contrast to conditions typically applied (over $160^{\circ} \mathrm{C}$ ), which may significantly reduce the costs. 


\section{Materials and Methods}

\subsection{Biological Material}

\subsubsection{Sugar Beet Pulp}

Fresh sugar beet pulp (SBP) was delivered from the Dobrzelin Sugar Factory (Poland). Due to the seasonality of sugar production, the fresh SBP was collected in the campaign period and stored at $-18{ }^{\circ} \mathrm{C}$ before use.

\subsubsection{Inoculum}

Anaerobic sludge was collected from the anaerobic mesophilic digester at the Municipal Wastewater Treatment Plant in Lodz, Poland and served as inoculum for batch experiments. The inoculum had total (TS) and volatile solids (VS) concentrations of $24.59 \mathrm{gTS} / \mathrm{kg}$ and $15.74 \mathrm{gVS} / \mathrm{kg}$ (Table 1), respectively.

\subsection{Experimental Setup and Operational Conditions}

\subsubsection{Sugar Beet Pulp Hydrolysis}

Sugar beet pulp hydrolysates were obtained by thermal and acidic pretreatment of SBP. Two experimental variants were performed-one with only thermal pretreatment and the other with addition of $2 \%$ or $5 \%$ sulfuric acid (by volume) followed by thermal treatment. These conditions were adopted to break down lignocellulosic structures of SBP in order to release furfural and easily biodegradable sugars for methane and hydrogen production. In the experiments with only thermal pretreatment, SBP was mixed with water in the proportion of $1 \mathrm{~kg}$ of biomass to $5 \mathrm{~kg}$ of water and treated in a $8 \mathrm{dm}^{3}$ pressure reactor (Parr Instrument Company, series 4552) at $140{ }^{\circ} \mathrm{C}$ and under 4 bar pressure to achieve thermally treated sugar beet pulp (TSBP). In the experiments with thermochemical pretreatment, $1 \mathrm{~kg}$ of SBP was mixed with $58 \mathrm{~mL}$ of sulfuric acid and $4953 \mathrm{~mL}$ of water, and then subjected to thermal treatment (as described above) to achieve thermochemically treated sugar beet pulp (TASBP) (2 vol\%: $55 \mathrm{~g}$ of $95 \% \mathrm{H}_{2} \mathrm{SO}_{4}$ and $4945 \mathrm{~g}$ of water; $5 \mathrm{vol} \%$ : $141 \mathrm{~g}$ of $95 \% \mathrm{H}_{2} \mathrm{SO}_{4}$ and $4859 \mathrm{~g}$ of water). The pressure reactor was characterized by high thermal inertia. It took about 70 minutes to heat the contents of the reactor from room temperature to $140{ }^{\circ} \mathrm{C}$. The reaction at $0 \mathrm{~h}$ means the time it took to heat the contents to the set temperature without the use of a thermostat. The cooling of the reactor for 15 minutes to achieve $80^{\circ} \mathrm{C}$ was carried out by forcing the water to cycle in the steel inside cooler. Sugar beet pulp enzymatic hydrolysates (HSBP) were obtained by using a mixture of two commercial multienzyme preparations: Viscozyme and Ultraflo Max (Novozymes, Denmark). Enzymatic hydrolysis of sugar beet pulp was conducted under optimal conditions established in the previous research $[7,45]$, at the temperature of $45^{\circ} \mathrm{C}$ and $\mathrm{pH}$ of 5.0 with mixing for $10 \mathrm{~h}$.

\subsubsection{Dark Fermentation}

In this work sugar beet pulp hydrolysates (HSBP, TSBP, TASBP) were mixed with inoculum to achieve the inoculum to substrate $\left(X_{\mathrm{o}} / S_{\mathrm{o}}\right)$ ratio of 2:1 based on volatile solids concentration (Table 1) [46]. The experiments were performed using batch fermentation systems consisting of $1 \mathrm{dm}^{3}$ glass bottles, each with a working volume of $0.7 \mathrm{dm}^{3}$. The daily biogas production was measured by a water displacement method; for this purpose each bottle was connected to a $1 \mathrm{dm}^{3}$ gas collecting tank (Figure 1). Before shutting down, the air in the headspace of each bottle was removed by blowing with nitrogen gas for about 5 minutes to maintain anaerobic conditions. The bottles were then incubated at $35^{\circ} \mathrm{C}$ in a thermostat, which maintained the constant mesophilic temperature and were manually shaken twice a day. Each experiment was continued to the point at which only residual or no biogas production occurred. The dark fermentation trials ran for 14 days. In case of DF experiments, in order to eliminate hydrogen consuming microorganisms, mainly methanogens, the substrate with inoculum 
were first treated with a $20 \% \mathrm{H}_{2} \mathrm{SO}_{4}$ solution to adjust the $\mathrm{pH}$ value to 5.5 and then heated in a laboratory dryer at $80{ }^{\circ} \mathrm{C}$ for 1.5 hours. These operations were performed in order to not only inactivate hydrogen consuming bacteria and methanogens but also to provide optimal conditions for hydrogen generation [41]. This procedure was not applied for anaerobic digestion (AD) experiments. All the tests were conducted in triplicates, the results of which are expressed as the averages.

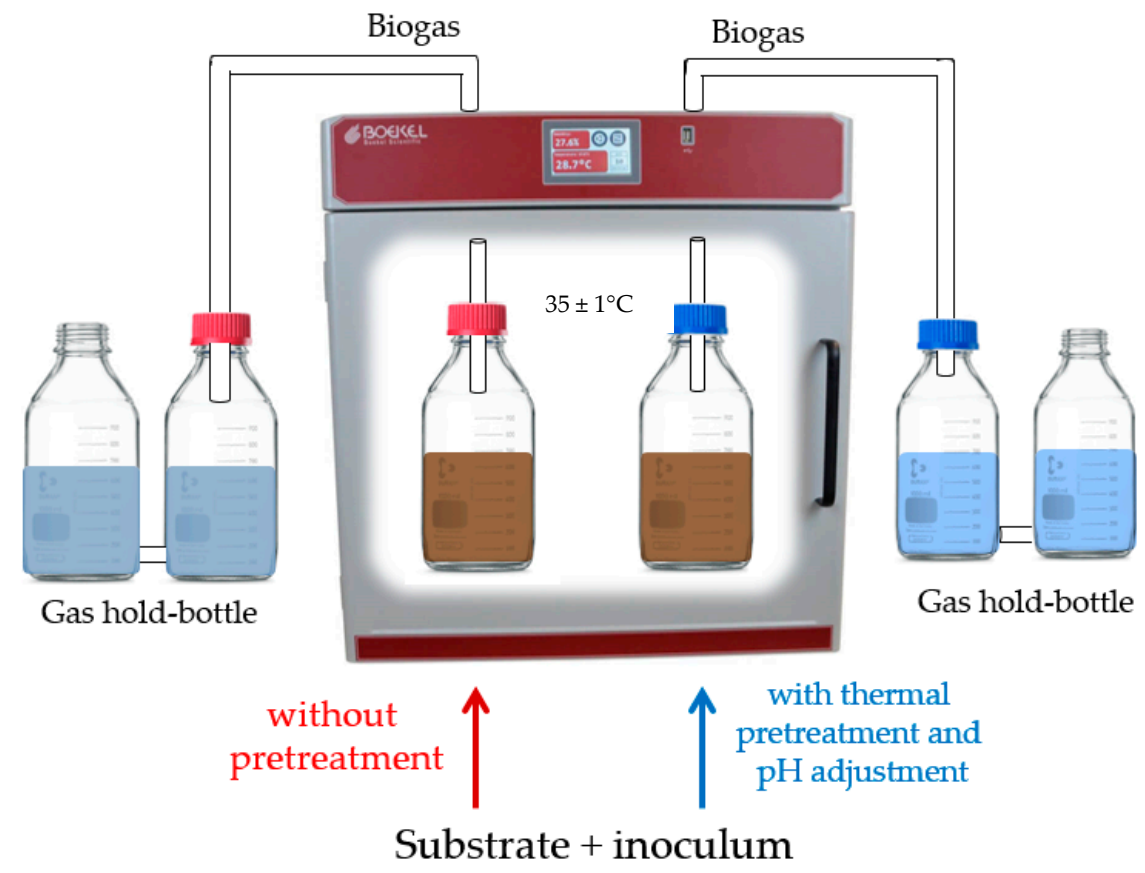

Figure 1. Laboratory set-up.

\subsection{Analytical Methods}

\subsubsection{Substrate Characterization}

Total solid (TS), volatile solid (VS), and pH was measured by the methods described in Standard Methods for the Examination of Water and Wastewater [47]. Chemical oxygen demand (COD), ammonium nitrogen, and orthophosphates were determined using a DR6000 spectrophotometer (Hach-Lange, Loveland, USA) and Hach-Lange tests no. 8000, 8038 and 8048, respectively. The tests were conducted according to the manufacturer's instructions.

Individual volatile fatty acids (acetic, formic/propionic, i-butyric, n-butyric, i-valeric, n-valeric, i-caproic, n-caproic and heptanoic acid) were determined by GC (gas chromatography), using an Agilent 7890A GC chromatograph (Agilent Technologies, Santa Clara, CL, USA) equipped with a flame ionization detector (FID). The components were separated using a column: DB-FFAP (a nitroterephthalic-acid-modified polyethylene glycol (PEG) column of high polarity; $30 \mathrm{~m} \times$ $0.32 \mathrm{~mm}$, film $0.25 \mu \mathrm{m}$, Agilent Technologies, Santa Clara, CL, USA). Agilent J and W DB-FFAP was a nitroterephthalic-acid-modified polyethylene glycol (PEG) column of high polarity applied for the analysis of volatile fatty acids and phenols. The operating conditions for the GC-FID analysis were as follows: injector, $220^{\circ} \mathrm{C}$, split 1:10; FID, $220^{\circ} \mathrm{C}, \mathrm{H}_{2} 30 \mathrm{~mL} / \mathrm{min}$, air $400 \mathrm{~mL} / \mathrm{min}$, makeup He $20 \mathrm{~mL} / \mathrm{min}$; column, initial $100{ }^{\circ} \mathrm{C}$ initial, $1.5 \mathrm{~min}$ hold, $8{ }^{\circ} \mathrm{C} / \mathrm{min}, 20{ }^{\circ} \mathrm{C}$ final $4.0 \mathrm{~min}$ hold. Helium was used as the carrier gas (flow rate of $1.2 \mathrm{~mL} / \mathrm{min}$ ). The quantitative determination was performed using the internal standard technique through a four-point calibration curve in the concentration range for each of acids 2.0-8.0 mM. Reference substances: reference mixture of 10 lower fatty acids at a concentration of $10 \mathrm{mM}$ each (Sigma), 2-ethyl-butyric acid 98\% IS (Sigma). The samples for volatile fatty acid (VFA) analyses were prepared by centrifuging the digestate at $4000 \mathrm{rpm}$, for 10 minutes. 


\subsubsection{Monosaccharide Content}

The monosaccharide profile of sugars in the stillage obtained after furfural production was determined by UV-spectrophotometry (Thermo Scientific Multiskan GO; Thermo Fisher Scientific, Munich, Germany) and by using Megazyme Kits (Megazyme Ltd., Bray, Inc; Ireland) following the manufacturer's procedure. For glucose, mannose and fructose determination-D-Mannose, D-Fructose and D-Glucose assay kit (K-MANGL); for arabinose and galactose assay kit (K-ARGA); for galacturonic acid K-URONIC kit; for xylose-K-XYLOSE kit; for raffinose-K-RAFGA kit; for rhamnose-K-RHAMNOSE kit. Samples for monosaccharide content were prepared by centrifuging the digestate for 10 minutes at $4000 \mathrm{rpm}$.

\subsubsection{Methane and Hydrogen Potential Tests}

Biogas yield was monitored on a daily basis by the water displacement method, which is described elsewhere in the literature [48]. The content of $\mathrm{O}_{2}, \mathrm{CO}_{2}, \mathrm{CH}_{4}, \mathrm{H}_{2}$ and $\mathrm{H}_{2} \mathrm{~S}$ was measured by portable gas analyzer (Madur, GA-21 plus). In this study, the hydrogen yield was evaluated mainly on the VS basis in order to render our results comparable to other studies.

\subsubsection{Furfural}

Furfural concentrations were measured by GC-FID (Hewlett Packard 5890 Series II gas chromatograph equipped with a flame-ionizing detector and capillary column (Restek RTX-5: $30 \mathrm{~m} \times 0.53 \mathrm{~mm} \times 1.50 \mu \mathrm{m}$, Helium (Linde; $99.999 \%$ )). The operating conditions for the GC-FID analysis were as follows: flow rate of the carrier gas $30 \mathrm{~mL} / \mathrm{min}$; dispenser temperature $150{ }^{\circ} \mathrm{C}$; column temperature $60-150{ }^{\circ} \mathrm{C}$; initial temperature $60{ }^{\circ} \mathrm{C}$; start time $2 \mathrm{~min}$; temperature rise $2{ }^{\circ} \mathrm{C} / \mathrm{min}$; detector temperature $250^{\circ} \mathrm{C}$; injection volume $1 \mu \mathrm{L}$.

\subsection{Statistical Analysis}

All the analytical tests were performed in triplicates. The mean and standard deviation values, error bars were calculated in Microsoft Excel 2010 and in R version 3.5.0.

\section{Results and Discussion}

\subsection{Composition of Sugar Beet Pulp Hydrolysates}

In this study, the effect of thermal and chemical hydrolysis on the degradation of the complex structure of SBP was evaluated on the basis of sugar profiles, furfural production, and hydrogen and methane yields. It must be mentioned that production of furfural from lignocellulose biomass has been described in the literature, and the authors used various acids and temperature conditions: hydrochloric acid with $65 \%$ furfural yield (under $170{ }^{\circ} \mathrm{C}$ reaction temperature) [49], sulfuric acid also with $65 \%$ furfural yield $\left(230^{\circ} \mathrm{C}\right)$ [50], phosphoric acid with $60 \%$ yield $\left(200{ }^{\circ} \mathrm{C}\right)$ [51]. In contrast to these studies, we used relatively low concentrations of sulfuric acid combined with lower pretreatment temperature, which may be economically beneficial (Table 1). The experiments with thermal and thermochemical hydrolysis of sugar beet pulp are summarized in Table 2. With increasing time of hydrolysis and the amount of acid used, the volatile solids value of SBP decreased to achieve as low as $24 \mathrm{~g} / \mathrm{kg}$ (TASBP-2) for thermochemical treatment. This was probably due to chemical destruction of carbohydrates (i.e., in Maillard reaction and formation of volatile compounds [52,53]), which was also visible by a strong color change after pretreatment from beige to dark brown and a caramel-like smell of hydrolysate. The application of acid also enhanced furfural yield during hydrolysis. The furfural production via thermal pretreatment alone was moderate and did not exceed $2 \mathrm{~g} / \mathrm{L}$. However, when combined thermochemical treatment was applied, especially at $5 \%$ sulfuric acid concentration, the furfural yield reached $12 \mathrm{~g} / \mathrm{L}$ (Table 1). Luo et al. [54]. achieved similar results for Pubescens (1.2\%) at a higher temperature $\left(160^{\circ} \mathrm{C}\right)$ with no addition of acid. The cited authors also applied microwave treatment at 
$200{ }^{\circ} \mathrm{C}$ and $\mathrm{H}_{2} \mathrm{O}-$ cyclohexane at $160^{\circ} \mathrm{C}$ but with no further improvement. In our study, the maximum temperature was established at $140^{\circ} \mathrm{C}$ mainly due to further use of hydrolysates for dark fermentation (DF) and anaerobic digestion (AD). However, temperatures above $160{ }^{\circ} \mathrm{C}$ contributed to the formation of phenolic compounds, including furfural, levulinic acid, vanillin and vanillin acid, all of which could inhibit hydrogen and methane production [55]. Much higher furfural yield was documented by Brazdausks et al. [56] who worked with birch wood (11\% based on the weight of material, at $147{ }^{\circ} \mathrm{C}$ for $90 \mathrm{~min})$. However, the birch wood hydrolysates contained much more lignin (24\%) than sugar beet pulp (1-3\%) and cellulose (45\% versus $22-30 \%$ ) while the amount of hemicellulose was comparable (around 25\%). In our study, all the substrates were rich in easily biodegradable monosaccharides, which are excellent for microorganisms. The predominant sugars released were pectin-associated sugars such as arabinose, galactose, galacturonic acid, glucose from cellulose, as well as traces of rhamnose, which is derived from rhamnogalacturonan as a part of pectin [3,6]. Enzymatic hydrolysis of SBP allowed for the high concentrations of glucose, fructose, raffinose and xylose with no furfural production and improved hydrogen yield, which is comparable to the sugars profile observed in the previous research [45] under identical experimental conditions. In contrast, thermal pretreatment also released sugars but at much lower concentrations than the values reported in hydrolysate after enzymatic treatment. A $2 \%$ addition of sulfuric acid accelerated both furfural production and the release of some sugars, especially arabinose, xylose and rafinose, whereas the concentrations of other sugars dropped. At a higher acid concentration of 5\% (TASBP-2) furfural, the maximum yield (12 g/L) was achieved while the concentration of reducing sugars was significantly lower than the corresponding values for TASBP-1 (Table 1). This was particularly visible for pentoses, which were degraded to furfural. Hence, the greater production of furfural (TASBP-1 and TASBP-2) resulted in a drop of sugar content in hydrolysates, which are necessary for both AD and DF (Table 1). On the other hand, the hydrolysates after thermochemical pretreatment still contained a certain amount of sugars, which could be used by microorganisms in further processes.

Table 1. Characteristic of substrates and parameters of pretreatment processes.

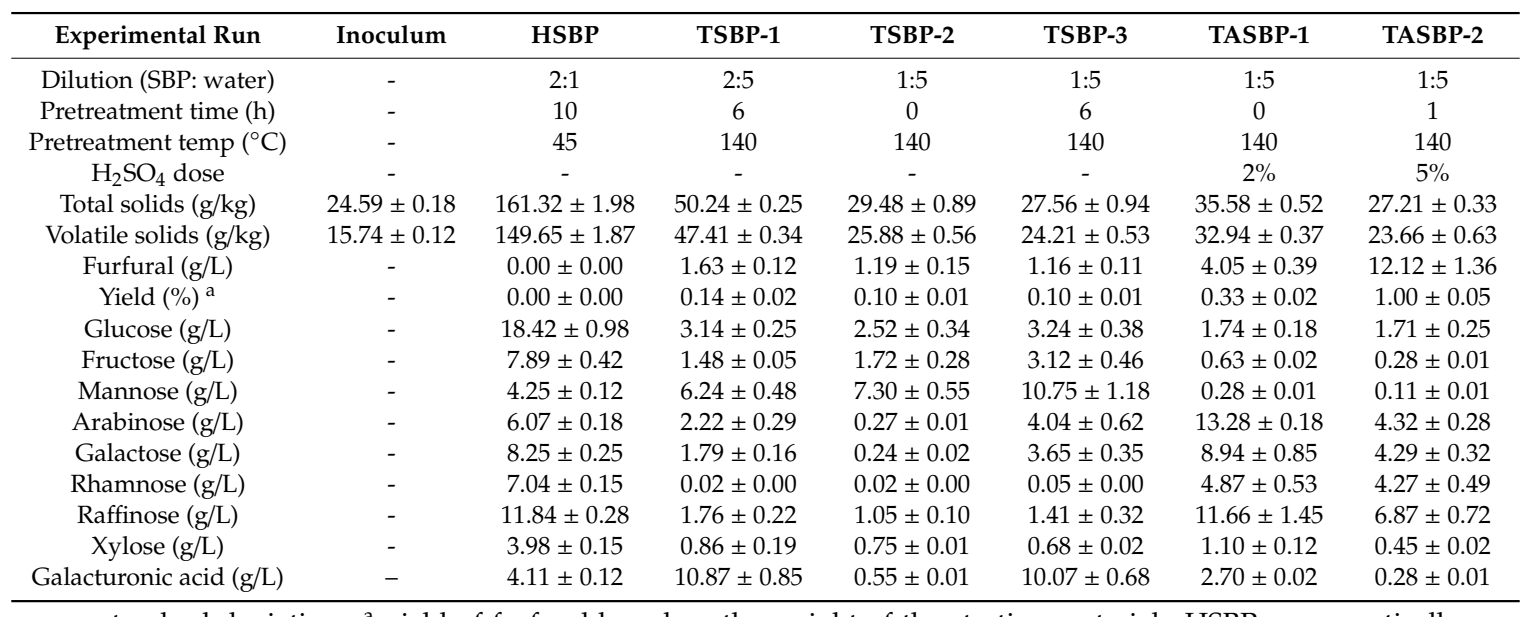

\pm standard deviation. ${ }^{a}$ yield of furfural based on the weight of the starting material. HSBP-enzymatically hydrolyzed sugar beet pulp. TSBP—-thermally pretreated sugar beet pulp. TASBP — thermochemically pretreated sugar beet pulp.

\subsection{Batch Tests}

The characteristics of pretreated SBP used for experiments is depicted in Table 1. The results of the batch digestion tests are summarized in Tables 2 and 3, and the plots with cumulative biogas yields are shown in Figures 2, 3 and A1.

The initial $\mathrm{pH}$ value for the methane digesters ranged from 7.05 to 7.33 and for the hydrogen digesters from 5.48 to 5.61 (Tables 2 and 3). During the experimental period, the average $\mathrm{pH}$ value decreased in each run for both methane and hydrogen digesters irrespective of the treated hydrolysates. 
Meanwhile, the $\mathrm{pH}$ drop for the trials without pretreatment was more pronounced in contrast to the other runs. The values of $\mathrm{pH}$ showed a decrease below 5.5, which could be linked to the release of volatile fatty acids (Table 5). Ziemiński and Wentel [55] observed a similar $\mathrm{pH}$ decrease (from 7.18 to 6.90) during anaerobic digestion of thermal-pressure pretreated sugar beet pulp.

The fermentability of sugar beet pulp (SBP) hydrolysates was determined by measuring the production of methane, hydrogen and organic acids. Sugar beet pulp is a good substrate for both anaerobic digestion and dark fermentation because it is mainly composed of carbohydrates. However, the compact lignocellulosic complex significantly hinders biological treatment. In our previous study, both fresh untreated and treated SBP were used for dark fermentative hydrogen production [45]. The hydrogen yield was only $31 \mathrm{dm}^{3} \mathrm{H}_{2} / \mathrm{kg}$ VS from fresh untreated sugar beet pulp, $103 \mathrm{dm}^{3} \mathrm{H}_{2} / \mathrm{kg}$ VS from steamed SBP, and exceeded $150 \mathrm{dm}^{3} \mathrm{H}_{2} / \mathrm{kg}$ VS from enzymatically hydrolyzed pulp. The difference between previous and current research in the amount of produced hydrogen after enzymatic hydrolysis may have resulted from the use of pulp collected in two different campaign seasons. Therefore, in this research, the hydrolysates after furfural production were used and compared with enzymatically treated pulp to determine their hydrogen and methane potential. The biogas production from enzymatically treated SBP was greater than the one obtained from the other hydrolysates. This resulted from the fact that the sugar beet pulp hydrolysate after enzymatic treatment contained more sugars than the products after thermal and chemical pretreatment since part of these sugars were involved in furfural production (Table 1). Moreover, the inhibitory role of furfural should not be excluded. During the experiments, the biogas volumes and composition were measured each day and the daily values were plotted to obtain the cumulative curves (Figures 2, 3 and A1). The highest biogas production was observed in the first two days of fermentation reaching a maximum after $24 \mathrm{~h}$ and practically stopped after 3 days for hydrogen experiments. Only in experimental runs of HSBP was hydrogen production extended to 8 days (Figure A1A,C). The first series of experiments were performed with neither $\mathrm{pH}$ correction nor thermal pretreatment of the substrates and inoculum, and data of these runs is depicted in Table 2. The greatest methane production in these runs was recorded for sugar beet pulp (SBP) after enzymatic hydrolysis $\left(402 \mathrm{dm}^{3} \mathrm{CH}_{4} / \mathrm{kg} \mathrm{VS}\right.$ ), whereas neither thermal nor thermochemical pretreatment improved methane yield (Table 2). The highest SMP of $391 \mathrm{dm}^{3} \mathrm{CH}_{4} / \mathrm{kg}$ VS was obtained for TSBP-2 which was lower than the production for steamed SBP (416 $\mathrm{dm}^{3} \mathrm{CH}_{4} / \mathrm{kg}$ VS) reported in the previous research [45]. This could be due to the formation of phenolic compounds, which is dependent on the temperature applied. This corresponds to the findings of Ziemiński and Wentel [55], who achieved the highest methane yield ( $543 \mathrm{dm}^{3} \mathrm{CH}_{4} / \mathrm{kg} \mathrm{VS}$ ) while treating $\mathrm{SBP}$ at $120^{\circ} \mathrm{C}$. It must be mentioned, however, that in batch digestion experiments with enzymatically treated SBP, apart from relatively high methane yield of $402 \mathrm{dm}^{3} \mathrm{CH}_{4} / \mathrm{kg} \mathrm{VS}$, a significant hydrogen production of $113 \mathrm{dm}^{3} \mathrm{H}_{2} / \mathrm{kg}$ VS was also observed. Similarly, in the TSBP-1 experiment, the specific methane yield of $374 \mathrm{dm}^{3} \mathrm{CH}_{4} / \mathrm{kg}$ VS was accompanied with the yield of $93 \mathrm{dm}^{3} \mathrm{H}_{2} / \mathrm{kg} \mathrm{VS}$, whereas the corresponding values reported in TSBP-3 run were $391 \mathrm{dm}^{3} \mathrm{CH}_{4} / \mathrm{kg}$ VS and $81 \mathrm{dm}^{3} \mathrm{H}_{2} / \mathrm{kg}$ VS. This means that biogas obtained in these experiments had high calorific value due to a significant contribution of hydrogen of more than $10 \%$ by volume. Application of sulfuric acid for thermochemical pretreatment of SBP significantly improved furfural production but had a rather inhibitory effect on both methane and hydrogen yield. The production of methane reported in runs TASBP-1 and TASBP-2 was residual and did not exceed $40 \mathrm{dm}^{3} \mathrm{CH}_{4} / \mathrm{kg}$ VS. Methane production in those runs were supposed to be strongly affected by elevated furfural concentrations. Moreover, in TASBP hydrolysates, the concentrations of sugars were significantly lower compared to the corresponding values for the other hydrolysates, especially after enzymatic pretreatment. Another series of experiments was performed using thermal pretreatment and $\mathrm{pH}$ adjustment to 5.5, and the aim of these experiments was to evaluate potential of hydrogen production from SBP hydrolysates (Table 3). Interestingly, this operation did not avoid methane formation. The hydrogen yield from enzymatically hydrolyzed SBP (HSBP) was at a comparable level to the $\mathrm{H}_{2}$ production reported in experiments with no $\mathrm{pH}$ adjustment and thermal inactivation of methanogens. Regarding the experiments with thermally pretreated sugar 
beet pulp, the highest hydrogen production of $85 \mathrm{dm}^{3} \mathrm{H}_{2} / \mathrm{kg}$ VS was detected in the TSBP- 3 run, which also corresponded to the findings from the first series of experiments (Table 2). Much greater hydrogen production was achieved in the experiment with hydrolysates from thermochemical pretreatment using $2 \%$ sulfuric acid (TASPB-1). In that run, the production of hydrogen reached $220 \mathrm{dm}^{3} \mathrm{H}_{2} / \mathrm{kg}$ VS (as much as $49 \%$ of the biogas volume) and was the highest in the whole study. A similar hydrogen yield of $252 \mathrm{dm}^{3} \mathrm{H}_{2} / \mathrm{kg}$ VS was achieved from sugar beet stillage (after ethanol production) derived from the same SBP, and reported in the previous investigation [57]. However, other researchers working with similar substrates obtained lower hydrogen yields, for instance up to $164 \mathrm{dm}^{3} \mathrm{H}_{2} / \mathrm{kg}$ VS from distillery wastewater [36] or $103 \mathrm{dm}^{3} \mathrm{H}_{2} / \mathrm{kg}$ VS from agricultural residues [34]. Furthermore, the production of hydrogen from food waste reported by Angeriz-Campoy et al. [30] and Nathao et al. [27] was even lower and did not exceed $55 \mathrm{dm}^{3} \mathrm{H}_{2} / \mathrm{kg}$ VS. In contrast, Dhar et al. [38] obtained $3.2 \mathrm{~mol} \mathrm{H}_{2} / \mathrm{mol}$ hexose from sugar beet juice (compared to the calculated amount of $1.7 \mathrm{~mol} \mathrm{H}_{2} / \mathrm{mol}$ glucose in our study), whereas Singh et al. [58,59], reported even as much as $8 \mathrm{~mol} \mathrm{H}_{2} / \mathrm{mol}$ glucose, however, they worked with pure cultures and higher temperatures of the dark fermentation process.

When the concentration of sulfuric acid used for thermochemical pretreatment was increased to $5 \%$ (TASBP-2), the hydrogen yield from the hydrolysate was much lower $\left(67 \mathrm{dm}^{3} \mathrm{H}_{2} / \mathrm{kg}\right.$ VS). In both TASBP processed, no methane was detected in biogas. Hence, it seems that sulfuric acid used for pretreatment stimulates both furfural and hydrogen production but only when used in low amounts ( $2 \%$ in this study). Another important finding is that hydrolysates obtained in thermal and thermochemical pretreatment, which gave the highest methane yields, were not suitable for hydrogen production and vice versa. Only enzymatically treated sugar beet pulp was suitable for both processes. This is in contradiction to the findings of Arreola-Vargas et al. [40], who successfully produced hydrogen and methane from acid hydrolysates, however, they did not apply thermal pretreatment for the raw materials. The cited authors have also mentioned about negative effects on hydrogen production caused by weak acids, furans and phenolics present in hydrolysates.

Table 2. Parameters of the batch digestion tests without pretreatment.

\begin{tabular}{cccccc}
\hline Substrate & $\begin{array}{c}\text { Specific Gas } \\
\text { Production (SGP) } \\
\mathbf{d m}^{\mathbf{3}} / \mathbf{k g ~ V S}\end{array}$ & $\begin{array}{c}\text { Specific } \\
\text { Methane } \\
\text { Production } \\
\text { (SMP) dm }\end{array}$ & $\begin{array}{c}\text { Specific } \\
\text { Hydrogen } \\
\text { Production } \\
\mathbf{C H}_{\mathbf{4}} / \mathbf{k g ~ V S}\end{array}$ & $\begin{array}{c}\mathbf{p H}_{\text {initial }} \\
\mathbf{H}_{\mathbf{2}} / \mathbf{k g ~ V S}\end{array}$ & $\mathbf{p H}_{\text {final }}$ \\
\hline HSBP & $913.22 \pm 28.54$ & $402.26 \pm 21.51$ & $112.59 \pm 8.94$ & $7.25 \pm 0.02$ & $7.09 \pm 0.05$ \\
TSBP-1 & $945.22 \pm 130.93$ & $374.24 \pm 45.09$ & $93.42 \pm 15.61$ & $7.33 \pm 0.08$ & $7.14 \pm 0.01$ \\
TSBP-2 & $170.30 \pm 0.36$ & $83.34 \pm 0.52$ & $5.84 \pm 0.10$ & $7.08 \pm 0.05$ & $6.29 \pm 0.08$ \\
TSBP-3 & $894.50 \pm 15.78$ & $391.16 \pm 12.08$ & $80.68 \pm 3.60$ & $7.13 \pm 0.05$ & $6.76 \pm 0.02$ \\
TASBP-1 & $61.60 \pm 3.49$ & $40.16 \pm 4.85$ & $3.92 \pm 0.22$ & $7.05 \pm 0.01$ & $6.51 \pm 0.01$ \\
TASBP-2 & $36.95 \pm 4.43$ & $11.82 \pm 1.35$ & $0.77 \pm 0.11$ & $7.11 \pm 0.05$ & $6.34 \pm 0.01$ \\
\hline
\end{tabular}

\pm standard deviation. HSBP—enzymatically hydrolyzed sugar beet pulp. TSBP—-thermally pretreated sugar beet pulp. TASBP—-thermochemically pretreated sugar beet pulp. 
Table 3. Parameters of the batch digestion tests with $\mathrm{pH}$ adjustment and thermal pretreatment.

\begin{tabular}{|c|c|c|c|c|c|}
\hline Substrate & $\begin{array}{c}\text { Specific Gas } \\
\text { Production (SGP) } \\
\mathrm{dm}^{3} / \mathrm{kg} \text { VS }\end{array}$ & $\begin{array}{l}\text { Specific } \\
\text { Methane } \\
\text { Production } \\
(\mathrm{SMP}) \mathrm{dm}^{3} \\
\mathrm{CH}_{4} / \mathrm{kg} \mathrm{VS}\end{array}$ & $\begin{array}{c}\text { Specific } \\
\text { Hydrogen } \\
\text { Production } \\
\text { (SHP) dm } \\
\mathrm{H}_{2} / \mathbf{k g ~ V S}\end{array}$ & $\mathrm{pH}_{\text {initial }}$ & $\mathrm{pH}_{\text {final }}$ \\
\hline HSBP & $197.39 \pm 31.21$ & $7.23 \pm 1.79$ & $109.89 \pm 13.58$ & $5.54 \pm 0.04$ & $5.32 \pm 0.01$ \\
\hline TSBP-1 & $22.60 \pm 3.23$ & $1.95 \pm 0.28$ & $13.01 \pm 1.86$ & $5.61 \pm 0.02$ & $5.36 \pm 0.01$ \\
\hline TSBP-2 & $82.29 \pm 3.76$ & $4.46 \pm 0.17$ & $15.67 \pm 0.62$ & $5.49 \pm 0.01$ & $5.18 \pm 0.02$ \\
\hline TSBP-3 & $200.87 \pm 32.28$ & $32.43 \pm 3.80$ & $85.44 \pm 36.08$ & $5.48 \pm 0.04$ & $5.37 \pm 0.05$ \\
\hline TASBP-1 & $447.22 \pm 5.17$ & $0.00 \pm 0.00$ & $219.67 \pm 2.54$ & $5.54 \pm 0.05$ & $5.40 \pm 0.04$ \\
\hline TASBP-2 & $214.67 \pm 4.92$ & $0.00 \pm 0.00$ & $67.08 \pm 1.54$ & $5.61 \pm 0.02$ & $5.22 \pm 0.01$ \\
\hline
\end{tabular}

\pm standard deviation. HSBP-enzymatically hydrolyzed sugar beet pulp. TSBP—-thermally pretreated sugar beet pulp. TASBP - thermochemically pretreated sugar beet pulp.

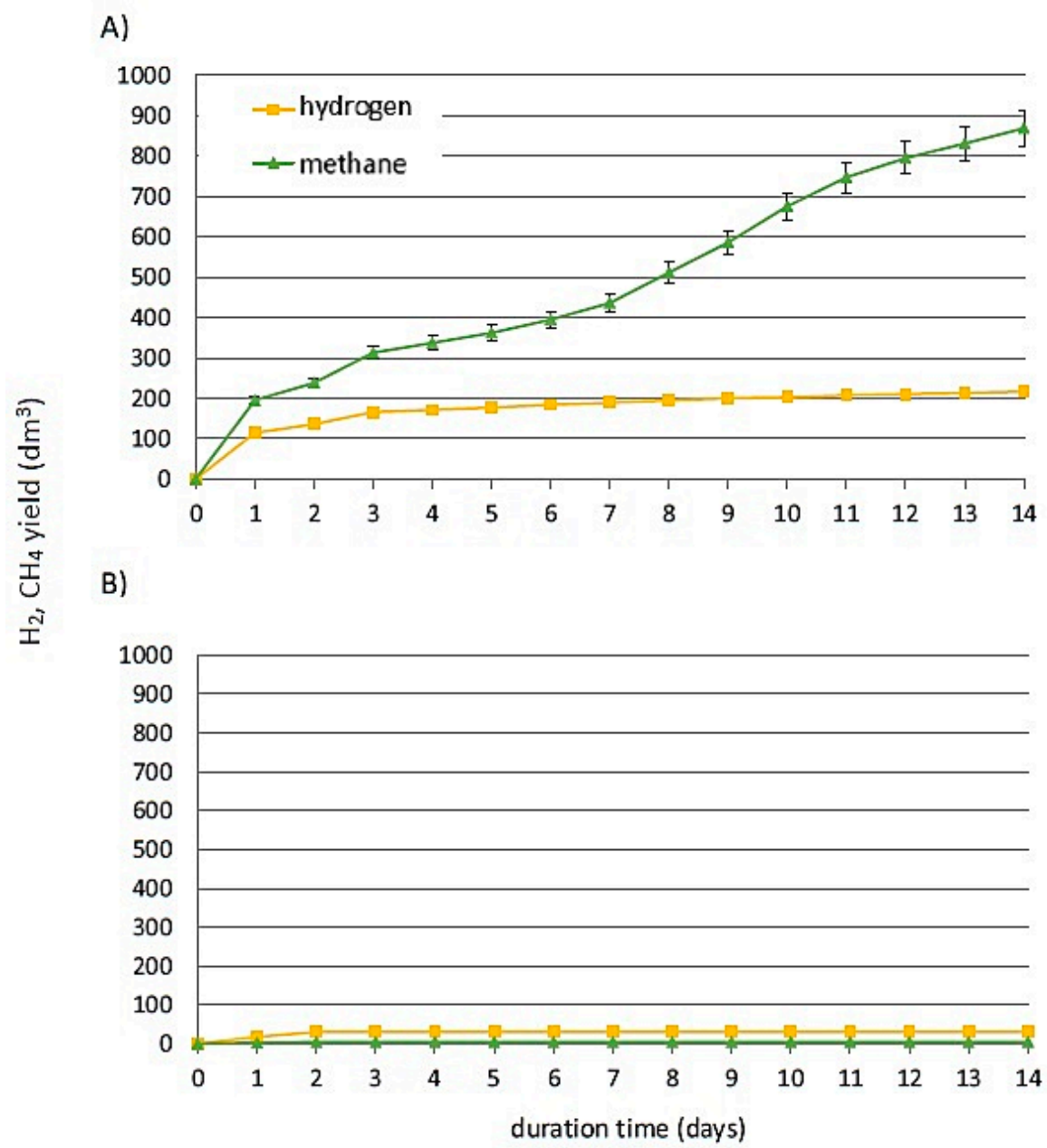

Figure 2. Cumulative hydrogen and methane productions for TSBP-1without pretreatment (A) and with $\mathrm{pH}$ adjustment followed by thermal pretreatment (B). 


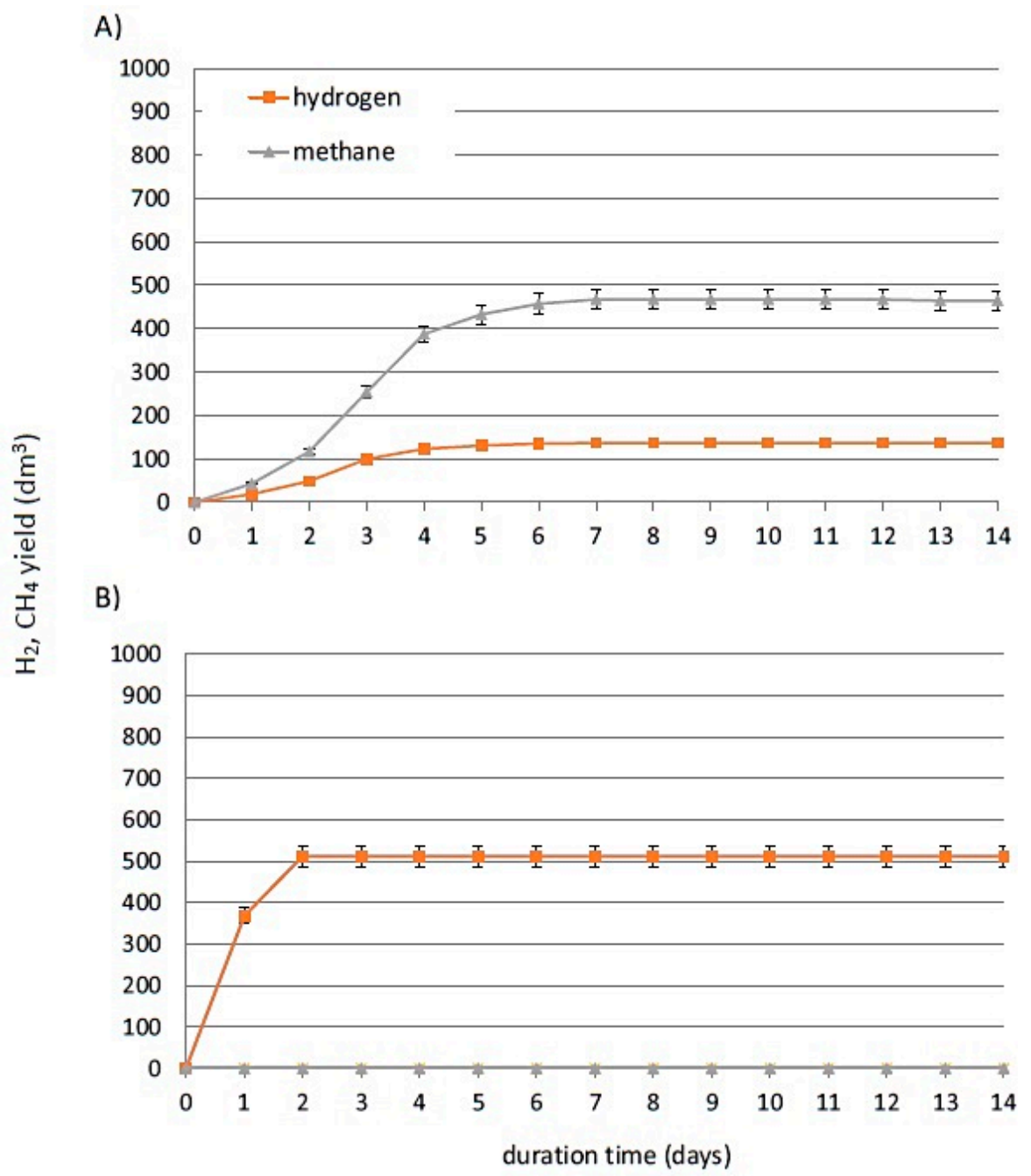

Figure 3. Cumulative hydrogen and methane production for TASBP-1 without pretreatment (A) and with $\mathrm{pH}$ adjustment followed by thermal pretreatment $(\mathbf{B})$.

Table 4 shows changes in ammonium-nitrogen and phosphates contents for all tested hydrolysates during anaerobic digestion and dark fermentation. Generally, greater ammonia concentrations in the digestates corresponded with higher biogas yields (hydrogen, methane or both gases). In our previous research [45] carbon (62.3\%), nitrogen (5.8\%) and phosphorus (4.9\%) content in SBP has been determined. In addition, carbon/nitrogen ratio amounted 10.74, which is relatively low. However, several papers have been published regarding adequate nitrogen concentrations for improving hydrogen production, but it is not possible to define an optimal $\mathrm{C} / \mathrm{N}$ ratio due to the differences between the configuration and operation of the fermentative process. The highest ammonia concentration was detected for enzymatically hydrolyzed SBP, which produced as much as $913 \mathrm{dm}^{3} / \mathrm{kg}$ VS of biogas (with $402 \mathrm{dm}^{3} \mathrm{CH}_{4} / \mathrm{kg}$ VS plus $113 \mathrm{dm}^{3} \mathrm{H}_{2} / \mathrm{kg}$ VS) (Table 4). In contrast, the methane experiments with thermochemically treated SBP (TASPB-1 and TASBP-2) gave very low biogas yields (Table 2), and the digestates from these processes contained only 431-489 mg/L of ammonium nitrogen (Table 4). Hence, it is clearly seen that higher ammonia release was due to greater digestion rate measured by biogas yield (methane, hydrogen or both). Regarding the behavior of phosphates, the highest concentrations of this nutrient were also determined in digestates from anaerobic treatment of enzymatically hydrolyzed SBP. Conversely, the lowest phosphate concentrations were detected in the digestates after anaerobic digestion of thermochemically treated SBP (especially TASBP-2). This could suggest partial fixation of phosphates during rapid thermal and especially thermochemical pretreatment. 
Table 4. Concentrations of ammonia and phosphates in the digestates.

\begin{tabular}{|c|c|c|c|c|}
\hline Substrate & $\mathrm{N}-\mathrm{NH}_{4}(\mathrm{mg} / \mathrm{L})$ & $\mathrm{P}-\mathrm{PO}_{4}{ }^{3}(\mathrm{mg} / \mathrm{L})$ & $\mathrm{N}-\mathrm{NH}_{4}(\mathrm{mg} / \mathrm{L})$ & $\mathrm{P}^{-\mathrm{PO}_{4}}{ }^{3}(\mathrm{mg} / \mathrm{L})$ \\
\hline & \multicolumn{2}{|c|}{ Without Pretreatment } & \multicolumn{2}{|c|}{ With pH Adjustment and Thermal Pretreatment } \\
\hline HSBP & $825 \pm 0.02$ & $1665 \pm 0.05$ & $797 \pm 0.02$ & $1580 \pm 0.02$ \\
\hline TSBP-1 & $751 \pm 0.02$ & $1552 \pm 0.05$ & $662 \pm 0.02$ & $1220 \pm 0.02$ \\
\hline TSBP-2 & $623 \pm 0.05$ & $1020 \pm 0.02$ & $524 \pm 0.02$ & $1560 \pm 0.05$ \\
\hline TSBP-3 & $543 \pm 0.02$ & $1032 \pm 0.01$ & $790 \pm 0.01$ & $1460 \pm 0.05$ \\
\hline TASBP-1 & $489 \pm 0.01$ & $964 \pm 0.02$ & $800 \pm 0.05$ & $1030 \pm 0.01$ \\
\hline TASBP-2 & $431 \pm 0.01$ & $904 \pm 0.02$ & $725 \pm 0.05$ & $980 \pm 0.05$ \\
\hline
\end{tabular}

\pm standard deviation. HSBP—enzymatically hydrolyzed sugar beet pulp. TSBP—-thermally pretreated sugar beet pulp. TASBP—-thermochemically pretreated sugar beet pulp.

\subsection{Volatile Fatty Acid Productions}

Fermentative hydrogen production is accompanied by the production of liquid metabolites such as volatile organic acids (VFAs). Table 5 summarizes the concentrations of individual acids measured in the digestates from $\mathrm{H}_{2}$ experiments when the dark fermentation process reached maximum hydrogen yield. The concentrations of liquid metabolite components obviously increased with increasing total sugar concentrations in the feedstock (Table 1). Generally, there was no clear relationship between type of pretreatment applied, hydrogen yield, and VFA concentration in the digestate. However, the reactors operated with thermally pretreated beet pulp (TSBP) produced digestates containing more acids, which corresponded with the lower hydrogen yields in these runs. Conversely, the digestates obtained from DF of enzymatic or thermochemical pretreatment of beet pulp (HSBP, TASBP) contained fewer fatty acids, which may suggest that these metabolic products were utilized during hydrogen production. Another possible explanation is utilization of fatty acids for synthesis of organic chemicals like levulinic acid under highly acidic conditions, however, this statement should be confirmed in further research. The main carboxylic acid found in the digestates was acetic acid while propionic and butyric acids were found in lower concentrations. The above VFAs, particularly acetate and butyrate, are normally generated not only during dark fermentation but also during anaerobic organic acid production from carbohydrate rich substrates [25]. The exception is valeric acid, the concentration of which was $126 \mathrm{mg} / \mathrm{L}$ in the TASBP- 1 run in which the highest hydrogen yield was achieved (Table 5). Several studies reported the inhibitory effects of propionate on fermentative methane and hydrogen production [60,61]. Fang et al. [62] found that methane production from propionic acid is slower than from acetic acid and butyric acids. Moreover, propionate could inhibit the growth of methanogens and $\mathrm{H}_{2}$-producing bacteria during $\mathrm{AD}$ and $\mathrm{DF}$ processes. Hence, from this reason, propionic acid is an undesirable intermediate product in $\mathrm{AD}$.

Table 5. Concentrations of individual organic acids in the digestates.

\begin{tabular}{ccccccc}
\hline Substrate/Experimental Run & HSBP & TSBP-1 & TSBP-2 & TSBP-3 & TASBP-1 & TASBP-2 \\
\hline Acetic acid (g/L) & 0.8855 & 1.0775 & 0.9355 & 0.9930 & 0.7685 & 0.6235 \\
Propionic acid (g/L) & 0.1280 & 0.0780 & 0.1445 & 0.2335 & 0.0890 & 0.0535 \\
i-Butyric acid (g/L) & 0.0255 & 0.1205 & 0.1005 & 0.2330 & 0.0210 & 0.0335 \\
n-Butyric acid (g/L) & 0.0315 & 0.0905 & 0.0480 & 0.0780 & 0.0440 & 0.0485 \\
i-Valeric acid (g/L) & 0.0000 & 0.0790 & 0.1025 & 0.0570 & 0.0795 & 0.0600 \\
n-Valeric acid (g/L) & 0.0000 & 0.0000 & 0.0000 & 0.0125 & 0.1265 & 0.0780 \\
i-Caproic acid (g/L) & 0.0000 & 0.0425 & 0.0145 & 0.0165 & 0.0000 & 0.0000 \\
n-Caproic acid (g/L) & 0.0180 & 0.0060 & 0.0055 & 0.0055 & 0.0065 & 0.0075 \\
i-Heptanoic acid (g/L) & 0.0080 & 0.0000 & 0.0000 & 0.0000 & 0.0000 & 0.0000 \\
Total VFA & 1.0965 & 1.4940 & 1.3510 & 1.6285 & 1.1350 & 0.9045 \\
\hline HSBP-enzymatically hydrolyzed sugar beet pulp. & TSBP-thermally pretreated sugar & beet & pulp. \\
TASBP-thermochemically pretreated sugar beet pulp. & & & &
\end{tabular}




\subsection{Mass and Energy Balance}

Figure 4 and Table 6 present the complete energy and mass balance for the integrated system, for all the experimental variants.

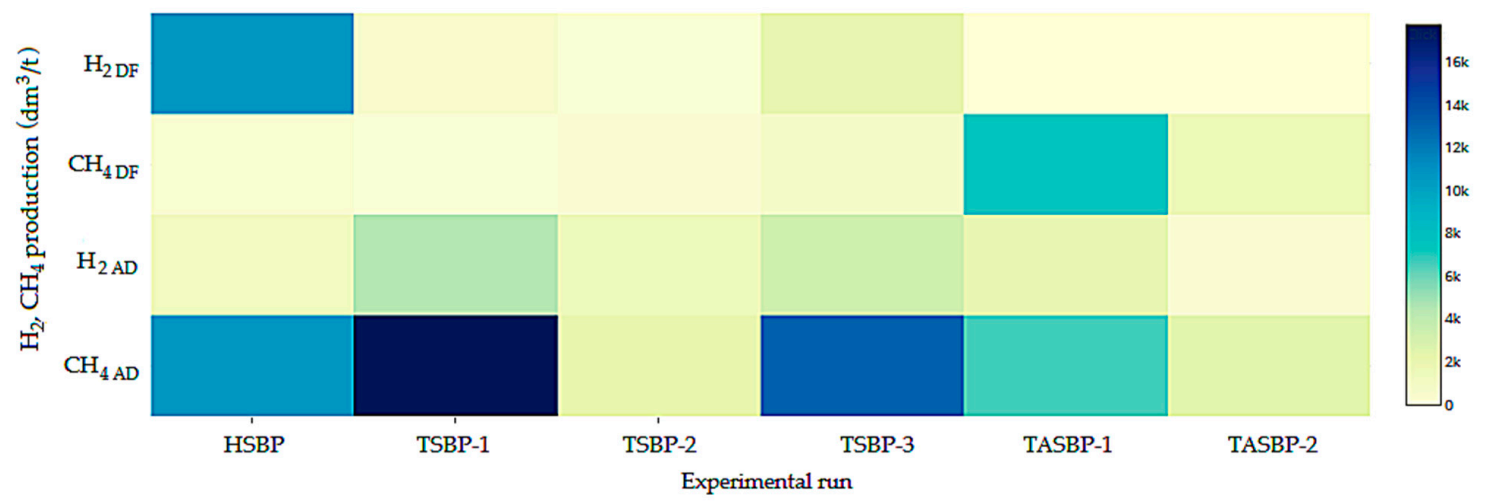

Figure 4. Heat map produced using data from mass balance. The columns of the heat map represent hydrolysates and the rows represent $\mathrm{H}_{2}$ and $\mathrm{CH}_{4}$ production $\left(\mathrm{CH}_{4 \mathrm{AD}}, \mathrm{H}_{2 \mathrm{AD}}\right.$-without pretreatment; $\mathrm{CH}_{4 \mathrm{DF}}, \mathrm{H}_{2 \mathrm{DF}}$-with pretreatment). Each cell is colorized based on the level of gas volume from $1 \mathrm{t}$ of fresh sugar beet pulp. (HSBP—enzymatically hydrolyzed sugar beet pulp; TSBP—thermally pretreated sugar beet pulp; TASBP — thermochemically pretreated sugar beet pulp).

Table 6. Simplified energy balance for experimental variants.

\begin{tabular}{|c|c|c|c|}
\hline Fuel & Volume $\left(\mathrm{m}^{3} / \mathrm{t}_{\mathrm{SBP}}\right)$ & $\begin{array}{l}\text { Specific Energy Yield } \\
\text { per Volume }\left(\mathbf{k W h} / \mathbf{m}^{3}\right)\end{array}$ & $\begin{array}{c}\text { Theoretical Energy } \\
\text { Yield (kWh/t }\end{array}$ \\
\hline \multicolumn{4}{|c|}{ TSBP-1 } \\
\hline Methane & 17.74 & 10.21 & +181.07 \\
\hline Hydrogen & 0.61 & 3.58 & +2.19 \\
\hline Heat treatment & - & - & -41.17 \\
\hline Total energy yield & - & - & $\sum 142.09$ \\
\hline \multicolumn{4}{|c|}{ TSBP-2 } \\
\hline Methane & 3.92 & 10.21 & +40.00 \\
\hline Hydrogen & 0.27 & 3.58 & +0.95 \\
\hline Heat treatment & - & - & -18.67 \\
\hline Total energy yield & - & - & $\sum 22.28$ \\
\hline \multicolumn{4}{|c|}{ TSBP-3 } \\
\hline Methane & 13.09 & 10.21 & +133.69 \\
\hline Hydrogen & 2.07 & 3.58 & +7.42 \\
\hline Heat treatment & - & - & -41.17 \\
\hline Total energy yield & - & - & $\sum 99.94$ \\
\hline \multicolumn{4}{|c|}{ TASBP-1 } \\
\hline Methane & 6.59 & 10.21 & +67.30 \\
\hline Hydrogen & 7.21 & 3.58 & +25.82 \\
\hline Heat treatment & - & - & -18.67 \\
\hline Total energy yield & - & - & $\sum 74.45$ \\
\hline \multicolumn{4}{|c|}{ TASBP-2 } \\
\hline Methane & 2.37 & 10.21 & +24.17 \\
\hline Hydrogen & 1.59 & 3.58 & +5.70 \\
\hline Heat treatment & - & - & -22.42 \\
\hline Total energy yield & - & - & $\sum 7.45$ \\
\hline
\end{tabular}

TSBP—-thermally pretreated sugar beet pulp. TASBP—-thermochemically pretreated sugar beet pulp. 
The calculated energy yield for heating SBP to $140{ }^{\circ} \mathrm{C}$ was $18.67 \mathrm{kWh} / \mathrm{t}$, whereas the energy yield to maintain this temperature for 6 hours was $22.50 \mathrm{kWh} / \mathrm{t}$. In the last experiment, heating at $140{ }^{\circ} \mathrm{C}$ was continued for only 1 hour, which gave the energy yield of only $3.75 \mathrm{kWh} / \mathrm{t}$. It was clearly seen that the highest energy yield could be achieved using thermal pretreatment of SBP at $140{ }^{\circ} \mathrm{C}$ for 6 hours and at higher SBP biomass content (Table 6). The energy in this case was almost exclusively derived from methane since only traces of hydrogen were released. On the other hand, the energy yield from SBP subjected to thermochemical pretreatment was twice lower $(74.45 \mathrm{kWh} / \mathrm{t}$ ) for TASBP-1 (Table 6). Greater addition of sulfuric acid (5\%) for pretreatment resulted in the highest furfural production but had a lethal impact on both methane and hydrogen production (Figure 4).

\section{Conclusions}

This study demonstrated that hydrolysates after furfural production from sugar waste biomass can potentially be used as fermentation media for methane and hydrogen production. The hydrolysates at the end of furfural production still contain high enough concentrations of sugars, which make them attractive for dark fermentation and anaerobic digestion. The experiments showed that the most promising option was the application of thermochemical pretreatment of sugar beet pulp using $140{ }^{\circ} \mathrm{C}$ and $2 \%$ sulfuric acid solution followed by dark fermentation. In this variant, around $4 \mathrm{~g} / \mathrm{L}$ of furfural and $220 \mathrm{dm}^{3} \mathrm{H}_{2} / \mathrm{kg}$ VS could be achieved. At higher sulfuric acid concentration of $5 \%$, the concentration of furfural admittedly increased to $12 \mathrm{~g} / \mathrm{L}$ but the hydrogen yield dropped significantly to $67 \mathrm{dm}^{3}$ $\mathrm{H}_{2} / \mathrm{kg}$ VS. Thus, in order to fully utilize the biotechnological potential of sugar beet pulp, furfural should be removed from hydrolysates before anaerobic digestion to maximize yields of both products.

Author Contributions: Conceptualization: W.C.-W., M.B. and J.T.; methodology: M.B., W.C.-W., J.T. and J.D.; writing-original draft preparation: W.C.-W., M.B., S.B. and J.D.; writing—review and editing: S.B., P.D. and I.W.; visualization: W.C.-W., M.B.; supervision: S.B., P.D. and I.W.; project administration: P.D.

Funding: Research were supported by National Centre for Research and Development Grant No. BIOSTRATEG 2/296369/5/NCBR/2016.

Conflicts of Interest: The authors declare that they have no competing interests.

\section{Abbreviations}

$\begin{array}{ll}\text { 5-HMF } & \text { 5-hydroxymethylfurfural } \\ \text { AD } & \text { anaerobic digestion } \\ \text { COD } & \text { chemical oxygen demand } \\ \text { DF } & \text { dark fermentation } \\ \text { FID } & \text { flame ionization detector } \\ \text { HSBP } & \text { sugar beet pulp enzymatic hydrolysate } \\ \text { LA } & \text { levulinic acid } \\ \text { OLR } & \text { organic loading rate } \\ \text { PEG } & \text { nitroterephthalic-acid-modified polyethylene glycol } \\ \text { SBP } & \text { sugar beet pulp } \\ \text { SGP } & \text { specific gas production } \\ \text { SHP } & \text { specific hydrogen production } \\ \text { SMP } & \text { specific methane production } \\ \text { SRT } & \text { solids retention time } \\ \text { TSBP } & \text { sugar beet pulp after thermal treatment } \\ \text { TASBP } & \text { sugar beet pulp after thermal and acidic treatment } \\ \text { TAN } & \text { total ammonium nitrogen } \\ \text { TS } & \text { total solids } \\ \text { VFA } & \text { volatile fatty acids } \\ \text { VS } & \text { volatile solids }\end{array}$




\section{Appendix A}

A. TSBP-2-without pretreatment

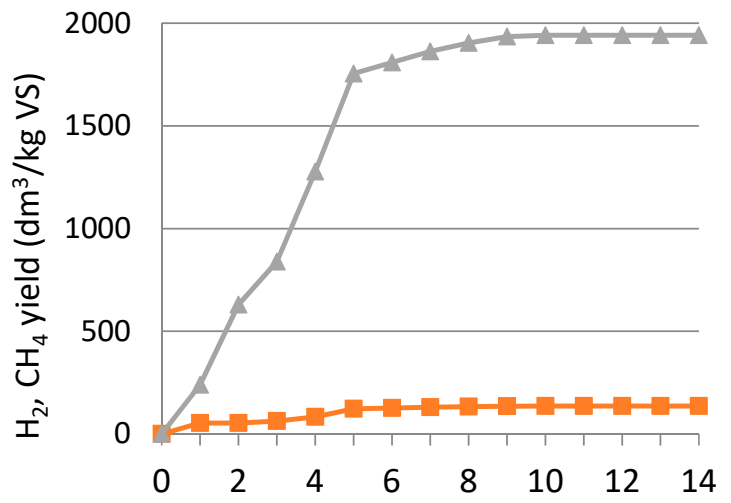

C. TSBP-3-without pretreatment

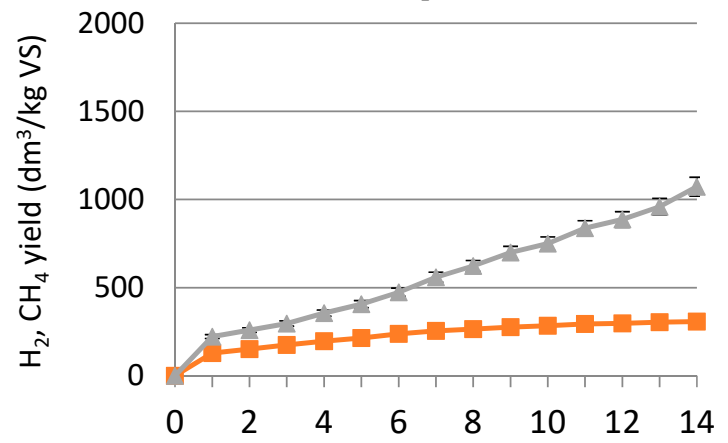

E. TASBP-2-without pretreatment

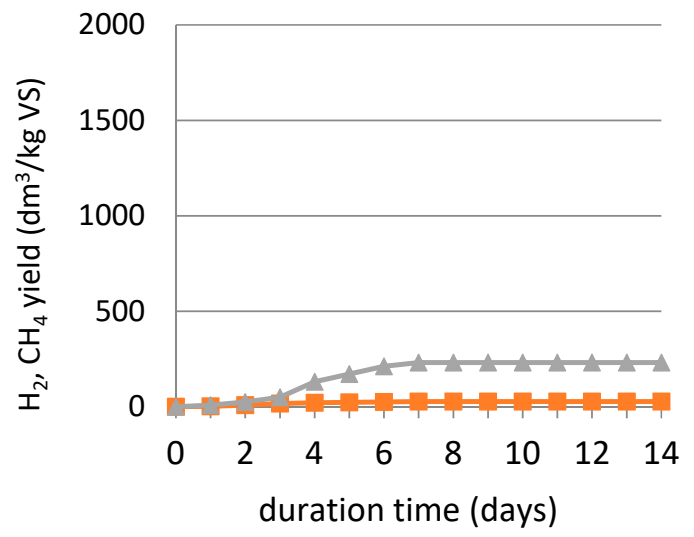

B. TSBP-2-with $\mathrm{pH}$ adjustment, thermal correction

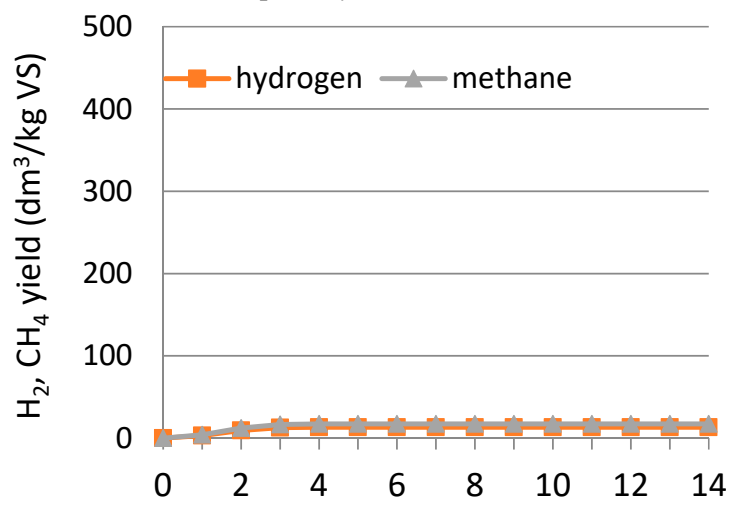

D. TSBP-3-with $\mathrm{pH}$ adjustment, thermal correction

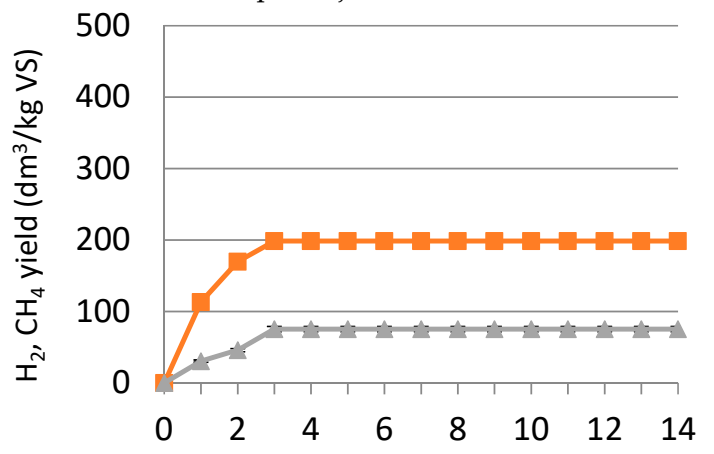

F. TASBP-2-with $\mathrm{pH}$ adjustment, thermal correction

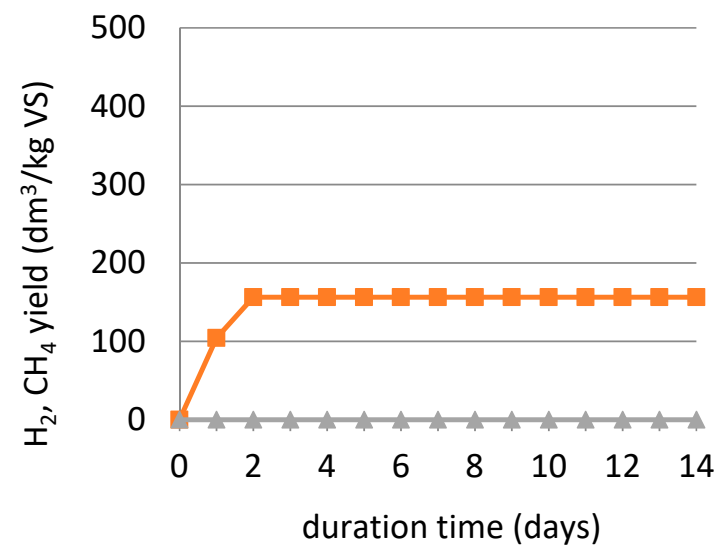

Figure A1. Cumulative hydrogen and methane production without pretreatment (A-TSBP-2, C-TSBP-3, E-TASBP-2) and with $\mathrm{pH}$ adjustment, thermal correction (B-TSBP-2, D-TSBP-3, F-TASBP-2).

\section{References}

1. Judzińska, A. Przemiany w polskim premyśle cukrowniczym w latach 2010-2016. Roczniki Naukowe Stowarzyszenia Ekonomistów Rolnictwa i Agrobiznesu; Stowarzyszenie Ekonomistów Rolnictwa i Agrobiznesu: Poznań, Poland, 2017; pp. 104-109.

2. Chudoba, L. Sugar market in Poland-currently and after the integration with the EU. In Rynek Cukru w Polsce Obecnie i po Integr. z Unia Eur; IERiGZ-PIB: Warszawa, Poland, 2004. 
3. Modelska, M.; Berlowska, J.; Kregiel, D.; Cieciura, W.; Antolak, H.; Tomaszewska, J.; Binczarski, M.; Szubiakiewicz, E.; Witonska, I. Concept for Recycling Waste Biomass from the Sugar Industry for Chemical and Biotechnological Purposes. Molecules 2017, 22, 1544. [CrossRef] [PubMed]

4. Tomaszewska, J.; Bieliński, D.; Binczarski, M.; Berlowska, J.; Dziugan, P.; Piotrowski, J.; Stanishevsky, A.; Witońska, I.A. Products of sugar beet processing as raw materials for chemicals and biodegradable polymers. RSC Adv. 2018, 8, 3161-3177. [CrossRef]

5. Güell, E.J.; Maru, B.T.; Chimentão, R.J.; Gispert-Guirado, F.; Constantí, M.; Medina, F. Combined heterogeneous catalysis and dark fermentation systems for the conversion of cellulose into biohydrogen. Biochem. Eng. J. 2015, 101, 209-219. [CrossRef]

6. Leijdekkers, A.G.M.; Bink, J.P.M.; Geutjes, S.; Schols, H.A.; Gruppen, H. Enzymatic saccharification of sugar beet pulp for the production of galacturonic acid and arabinose; a study on the impact of the formation of recalcitrant oligosaccharides. Bioresour. Technol. 2013, 128, 518-525. [CrossRef] [PubMed]

7. Berlowska, J.; Cieciura, W.; Borowski, S.; Dudkiewicz, M.; Binczarski, M.; Witonska, I.; Otlewska, A.; Kregiel, D. Simultaneous Saccharification and Fermentation of Sugar Beet Pulp with Mixed Bacterial Cultures for Lactic Acid and Propylene Glycol Production. Molecules 2016, 21, 1380. [CrossRef] [PubMed]

8. Concha, J.; Weinstein, C.; Zúñiga, M.E. Production of pectic extracts from sugar beet pulp with antiproliferative activity on a breast cancer cell line. Front. Chem. Sci. Eng. 2013, 7, 482-489. [CrossRef]

9. Zheng, Y.; Lee, C.; Yu, C.; Cheng, Y.-S.; Zhang, R.; Jenkins, B.M.; VanderGheynst, J.S. Dilute acid pretreatment and fermentation of sugar beet pulp to ethanol. Appl. Energy 2013, 105, 1-7. [CrossRef]

10. Berlowska, J.; Cieciura-Wloch, W.; Kalinowska, H.; Kregiel, D.; Borowski, S.; Pawlikowska, E.; Binczarski, M.; Witonska, I. Enzymatic Conversion of Sugar Beet Pulp: A Comparison of Simultaneous Saccharification and Fermentation and Separate Hydrolysis and Fermentation for Lactic Acid Production. Food Technol. Biotechnol. 2018, 56, 188. [CrossRef] [PubMed]

11. Mardones, W.; Callegari, E.; Eyzaguirre, J. Corncob and sugar beet pulp induce specific sets of lignocellulolytic enzymes in Penicillium purpurogenum. Mycology 2019, 10, 118-125. [CrossRef] [PubMed]

12. Liu, L.; Fishman, M.L.; Hicks, K.B.; Liu, C.-K. Biodegradable Composites from Sugar Beet Pulp and Poly (lactic acid). J. Agric. Food Chem. 2005, 53, 9017-9022. [CrossRef] [PubMed]

13. Cárdenas-Fernández, M.; Bawn, M.; Hamley-Bennett, C.; Bharat, P.K.V.; Subrizi, F.; Suhaili, N.; Ward, D.P.; Bourdin, S.; Dalby, P.A.; Hailes, H.C.; et al. An integrated biorefinery concept for conversion of sugar beet pulp into value-added chemicals and pharmaceutical intermediates. Faraday Discuss. 2017, 202, 415-431. [CrossRef]

14. Kucherov, F.A.; Romashov, L.V.; Galkin, K.I.; Ananikov, V.P. Chemical Transformations of Biomass-Derived C6-Furanic Platform Chemicals for Sustainable Energy Research, Materials Science, and Synthetic Building Blocks. ACS Sustain. Chem. Eng. 2018, 6, 8064-8092. [CrossRef]

15. Kougioumtzis, M.A.; Marianou, A.; Atsonios, K.; Michailof, C.; Nikolopoulos, N.; Koukouzas, N.; Triantafyllidis, K.; Lappas, A.; Kakaras, E. Production of 5-HMF from Cellulosic Biomass: Experimental Results and Integrated Process Simulation. Waste Biomass Valorization 2018, 9, 2433-2445. [CrossRef]

16. Yu, I.K.M.; Tsang, D.C.W. Conversion of biomass to hydroxymethylfurfural: A review of catalytic systems and underlying mechanisms. Bioresour. Technol. 2017, 238, 716-732. [CrossRef] [PubMed]

17. Li, Y.; Qi, B.; Wan, Y. Inhibitory effect of vanillin on cellulase activity in hydrolysis of cellulosic biomass. Bioresour. Technol. 2014, 167, 324-330. [CrossRef] [PubMed]

18. Kang, S.; Fu, J.; Zhang, G. From lignocellulosic biomass to levulinic acid: A review on acid-catalyzed hydrolysis. Renew. Sustain. Energy Rev. 2018, 94, 340-362. [CrossRef]

19. Pileidis, F.D.; Titirici, M.-M. Levulinic Acid Biorefineries: New Challenges for Efficient Utilization of Biomass. ChemSusChem 2016, 9, 562-582. [CrossRef] [PubMed]

20. Cai, C.M.; Nagane, N.; Kumar, R.; Wyman, C.E. Coupling metal halides with a co-solvent to produce furfural and 5-HMF at high yields directly from lignocellulosic biomass as an integrated biofuels strategy. Green Chem. 2014, 16, 3819-3829. [CrossRef]

21. Rasmussen, H.; Sørensen, H.R.; Meyer, A.S. Formation of degradation compounds from lignocellulosic biomass in the biorefinery: Sugar reaction mechanisms. Carbohydr. Res. 2014, 385, 45-57. [CrossRef]

22. Mittal, A.; Black, S.K.; Vinzant, T.B.; O’Brien, M.; Tucker, M.P.; Johnson, D.K. Production of Furfural from Process-Relevant Biomass-Derived Pentoses in a Biphasic Reaction System. ACS Sustain. Chem. Eng. 2017, 5, 5694-5701. [CrossRef] 
23. Luo, Y.; Li, Z.; Li, X.; Liu, X.; Fan, J.; Clark, J.H.; Hu, C. The production of furfural directly from hemicellulose in lignocellulosic biomass: A review. Catal. Today 2019, 319, 14-24. [CrossRef]

24. Li, X.; Jia, P.; Wang, T. Furfural: A Promising Platform Compound for Sustainable Production of C 4 and C 5 Chemicals. ACS Catal. 2016, 6, 7621-7640. [CrossRef]

25. Chu, C.-F.; Li, Y.-Y.; Xu, K.-Q.; Ebie, Y.; Inamori, Y.; Kong, H.-N. A pH- and temperature-phased two-stage process for hydrogen and methane production from food waste. Int. J. Hydrogen Energy 2008, 33, 4739-4746. [CrossRef]

26. Lee, D.-Y.; Ebie, Y.; Xu, K.-Q.; Li, Y.-Y.; Inamori, Y. Continuous $\mathrm{H}_{2}$ and $\mathrm{CH}_{4}$ production from high-solid food waste in the two-stage thermophilic fermentation process with the recirculation of digester sludge. Bioresour. Technol. 2010, 101, S42-S47. [CrossRef] [PubMed]

27. Nathao, C.; Sirisukpoka, U.; Pisutpaisal, N. Production of hydrogen and methane by one and two stage fermentation of food waste. Int. J. Hydrogen Energy 2013, 38, 15764-15769. [CrossRef]

28. Xiao, L.; Deng, Z.; Fung, K.Y.; Ng, K.M. Biohydrogen generation from anaerobic digestion of food waste. Int. J. Hydrogen Energy 2013, 38, 13907-13913. [CrossRef]

29. Wang, X.; Zhao, Y. A bench scale study of fermentative hydrogen and methane production from food waste in integrated two-stage process. Int. J. Hydrogen Energy 2009, 34, 245-254. [CrossRef]

30. Angeriz-Campoy, R.; Álvarez-Gallego, C.J.; Romero-García, L.I. Thermophilic anaerobic co-digestion of organic fraction of municipal solid waste (OFMSW) with food waste (FW): Enhancement of bio-hydrogen production. Bioresour. Technol. 2015, 194, 291-296. [CrossRef] [PubMed]

31. Elsamadony, M.; Tawfik, A. Potential of biohydrogen production from organic fraction of municipal solid waste (OFMSW) using pilot-scale dry anaerobic reactor. Bioresour. Technol. 2015, 196, 9-16. [CrossRef]

32. De Gioannis, G.; Friargiu, M.; Massi, E.; Muntoni, A.; Polettini, A.; Pomi, R.; Spiga, D. Biohydrogen production from dark fermentation of cheese whey: Influence of pH. Int. J. Hydrogen Energy 2014, 39, 20930-20941. [CrossRef]

33. Castelló, E.; Santos, C.G.Y.; Iglesias, T.; Paolino, G.; Wenzel, J.; Borzacconi, L.; Etchebehere, C. Feasibility of biohydrogen production from cheese whey using a UASB reactor: Links between microbial community and reactor performance. Int. J. Hydrogen Energy 2009, 34, 5674-5682. [CrossRef]

34. Li, Y.; Zhang, Z.; Zhu, S.; Zhang, H.; Zhang, Y.; Zhang, T.; Zhang, Q. Comparison of bio-hydrogen production yield capacity between asynchronous and simultaneous saccharification and fermentation processes from agricultural residue by mixed anaerobic cultures. Bioresour. Technol. 2018, 247, 1210-1214. [CrossRef] [PubMed]

35. Júnior, A.D.N.F.; Etchebehere, C.; Zaiat, M. High organic loading rate on thermophilic hydrogen production and metagenomic study at an anaerobic packed-bed reactor treating a residual liquid stream of a Brazilian biorefinery. Bioresour. Technol. 2015, 186, 81-88. [CrossRef] [PubMed]

36. Wicher, E.; Seifert, K.; Zagrodnik, R.; Pietrzyk, B.; Laniecki, M. Hydrogen gas production from distillery wastewater by dark fermentation. Int. J. Hydrogen Energy 2013, 38, 7767-7773. [CrossRef]

37. Wang, W.; Xie, L.; Luo, G.; Zhou, Q. Enhanced fermentative hydrogen production from cassava stillage by co-digestion: The effects of different co-substrates. Int. J. Hydrogen Energy 2013, 38, 6980-6988. [CrossRef]

38. Dhar, B.R.; Elbeshbishy, E.; Hafez, H.; Lee, H.S. Hydrogen production from sugar beet juice using an integrated biohydrogen process of dark fermentation and microbial electrolysis cell. Bioresour. Technol. 2015, 198, 223-230. [CrossRef] [PubMed]

39. Santos, S.C.; Rosa, P.R.F.; Sakamoto, I.K.; Varesche, M.B.A.; Silva, E.L. Continuous thermophilic hydrogen production and microbial community analysis from anaerobic digestion of diluted sugar cane stillage. Int. J. Hydrogen Energy 2014, 39, 9000-9011. [CrossRef]

40. Arreola-Vargas, J.; Flores-Larios, A.; González-Álvarez, V.; Corona-González, R.I.; Méndez-Acosta, H.O. Single and two-stage anaerobic digestion for hydrogen and methane production from acid and enzymatic hydrolysates of Agave tequilana bagasse. Int. J. Hydrogen Energy 2016, 41, 897-904. [CrossRef]

41. Lee, H.-S.; Vermaas, W.F.J.; Rittmann, B.E. Biological hydrogen production: Prospects and challenges. Trends Biotechnol. 2010, 28, 262-271. [CrossRef]

42. Zagrodnik, R.; Laniecki, M. The role of $\mathrm{pH}$ control on biohydrogen production by single stage hybrid darkand photo-fermentation. Bioresour. Technol. 2015, 194, 187-195. [CrossRef] 
43. Pachapur, V.L.; Kutty, P.; Pachapur, P.; Brar, S.K.; Le Bihan, Y.; Galvez-Cloutier, R.; Buelna, G. Seed Pretreatment for Increased Hydrogen Production Using Mixed-Culture Systems with Advantages over Pure-Culture Systems. Energies 2019, 12, 530. [CrossRef]

44. Ghimire, A.; Frunzo, L.; Pirozzi, F.; Trably, E.; Escudie, R.; Lens, P.N.L.; Esposito, G. A review on dark fermentative biohydrogen production from organic biomass: Process parameters and use of by-products. Appl. Energy 2015, 144, 73-95. [CrossRef]

45. Cieciura-Włoch, W.; Borowski, S. Biohydrogen production from waste of plant and animal origin via dark fermentation. J. Environ. Eng. Landsc. Manag. 2019, 27, 101-113. [CrossRef]

46. Tsapekos, P.; Kougias, P.G.; Treu, L.; Campanaro, S.; Angelidaki, I. Process performance and comparative metagenomic analysis during co-digestion of manure and lignocellulosic biomass for biogas production. Appl. Energy 2017, 185, 126-135. [CrossRef]

47. Rice, E.W.; Baird, R.B.; Eaton, A.D.; Clesceri, L.S. APHA Standard Methods for the Examination of Water and Waste Water, 22nd ed.; American Public Health Association; American Water Works Association; Water Environment Federation: Washington, DC, USA, 2012.

48. Zhong, W.; Zhang, Z.; Luo, Y.; Sun, S.; Qiao, W.; Xiao, M. Effect of biological pretreatments in enhancing corn straw biogas production. Bioresour. Technol. 2011, 102, 11177-11182. [CrossRef] [PubMed]

49. Chheda, J.N.; Román-Leshkov, Y.; Dumesic, J.A. Production of 5-hydroxymethylfurfural and furfural by dehydration of biomass-derived mono- and poly-saccharides. Green Chem. 2007, 9, 342-350. [CrossRef]

50. Montané, D. High-temperature dilute-acid hydrolysis of olive stones for furfural production. Biomass Bioenergy 2002, 22, 295-304. [CrossRef]

51. Marzialetti, T.; Olarte, M.B.V.; Sievers, C.; Hoskins, T.J.C.; Agrawal, P.K.; Jones, C.W. Dilute Acid Hydrolysis of Loblolly Pine: A Comprehensive Approach. Ind. Eng. Chem. Res. 2008, 47, 7131-7140. [CrossRef]

52. Sun, J.-B.; Severson, R.F.; Kays, S.J. Effect of heating temperature and microwave pretreatment on the formation of sugars and volatiles in jewel sweetpotato. J. Food Qual. 1994, 17, 447-456. [CrossRef]

53. Ariunbaatar, J.; Panico, A.; Frunzo, L.; Esposito, G.; Lens, P.N.L.; Pirozzi, F. Enhanced anaerobic digestion of food waste by thermal and ozonation pretreatment methods. J. Environ. Manag. 2014, 146, 142-149. [CrossRef]

54. Luo, J.; Xu, Y.; Zhao, L.; Dong, L.; Tong, D.; Zhu, L.; Hu, C. Two-step hydrothermal conversion of Pubescens to obtain furans and phenol compounds separately. Bioresour. Technol. 2010, 101, 8873-8880. [CrossRef] [PubMed]

55. Ziemiński, K.; Kowalska-Wentel, M. Effect of Different Sugar Beet Pulp Pretreatments on Biogas Production Efficiency. Appl. Biochem. Biotechnol. 2017, 181, 1211-1227. [CrossRef] [PubMed]

56. Brazdausks, P.; Vedernikovs, N.; Puke, M.; Kruma, I. Effect of the Acid Hydrolysis Temperature on the Conversion of Birch Wood Hemicelluloses into Furfural. Key Eng. Mater. 2014, 604, 245-248. [CrossRef]

57. Berlowska, J.; Pielech-Przybylska, K.; Balcerek, M.; Cieciura, W.; Borowski, S.; Kregiel, D. Integrated Bioethanol Fermentation/Anaerobic Digestion for Valorization of Sugar Beet Pulp. Energies 2017, 10, 1255. [CrossRef]

58. Singh, R.; White, D.; Demirel, Y.; Kelly, R.; Noll, K.; Blum, P. Uncoupling fermentative synthesis of molecular hydrogen from biomass formation in Thermotoga maritima. Appl. Environ. Microbiol. 2018. [CrossRef] [PubMed]

59. Singh, R.; Tevatia, R.; White, D.; Demirel, Y.; Blum, P. Comparative kinetic modeling of growth and molecular hydrogen overproduction by engineered strains of Thermotoga maritima. Int. J. Hydrogen Energy 2019, 44, 7125-7136. [CrossRef]

60. Ren, N. Mechanism and controlling strategy of the production and accumulation of propionic acid for anaerobic wastewater treatment. Sci. China Ser. B Chem. 2002, 45, 319. [CrossRef]

61. Wang, B.; Wan, W.; Wang, J. Inhibitory effect of ethanol, acetic acid, propionic acid and butyric acid on fermentative hydrogen production. Int. J. Hydrogen Energy 2008, 33, 7013-7019. [CrossRef]

62. Fang, H.H.; Yu, H. Mesophilic acidification of gelatinaceous wastewater. J. Biotechnol. 2002, 93, 99-108. [CrossRef]

(C) 2019 by the authors. Licensee MDPI, Basel, Switzerland. This article is an open access article distributed under the terms and conditions of the Creative Commons Attribution (CC BY) license (http://creativecommons.org/licenses/by/4.0/). 